\title{
COMMENT
}

\section{AN ASSESSMENT OF THE PENNSYLVANIA ESTATE GUARDIANSHIP INCOMPETENCY STANDARD}

In Pennsylvania, as in all other jurisdictions in the United States, ${ }^{1}$ legal machinery ${ }^{2}$ exists for declaring a person ${ }^{3}$ incompetent and placing his property ${ }^{4}$ under the control of a guardian. ${ }^{5}$ The machinery is activated upon petition by "any person interested in the alleged incompetent's welfare."6 Once a person is declared incompetent, his property is managed by a courtsupervised guardian and the incompetent is automatically placed under certain legal disabilities. ${ }^{7}$ The predecessors ${ }^{8}$ of the current statutory provision in Pennsylvania often have been called "preventative and protective" in nature, ${ }^{9}$ but, unfortunately, on occasion they have proved to be "preventative" of one's enjoyment of his property, and "protective" of the anticipated inheritance of an anxious prospective heir who sees in his aging relative's accelerating spending habits the danger that his ship may sink before it can come in. ${ }^{10}$

${ }^{1}$ See R. Allen, E. Ferster \& H. Weihofen, Mental Impairment and Legal INCOMPETENCY $144 \mathrm{n} .1$ (1968) [hereinafter cited as Allen].

2 Pa. Consol. STar. AnN. tit. 20, \$§ 5501, 5511 (1975).

${ }^{3}$ Only persons other than minors need be declared incompetent. See Williams Estate, 40 Pa. D. \& C.2d 718, 722 (Phila. County Orphans' Ct. 1966). The estates of minors are subject to guardianship under PA. Consol. STAT. ANN. tit. 20, §§ 5101-5167 (1975).

${ }^{4} \mathrm{~A}$ finding of incompetency may warrant the appointment of a guardian of one's estate or person or both, depending on the circumstances. Pa. Consol. Stat. Ann. tit. $20, \S 551$ (a) (1975). This Comment is concerned only with guardianships of the estate.

s Other jurisdictions use synonyms for "guardian," such as "committee," "conservator," "curator," "tutor," or "receiver." G. STEPHenson, Estates and Trusts 83 (rev. ed. 1955). For a general description of the history and nature of guardianship, see, e.g., Regan, Protective Services for the Elderly: Commitment, Guardianship, and Alternatives, 13 WM. \& MARY L. REV. 569, 602-07 (1972).

6 Pa. Consol. Stat. Ann. tit. 20, \$5511 (1975).

${ }^{7}$ See text accompanying notes 15-22 infra.

${ }^{8}$ See note 25 infra.

${ }^{9}$ See, e.g., Nagle Estate, 418 Pa. 170, 172, 210 A.2d 262, 264 (1965); Earnshaw Appeal, 187 Pa. Super. 124, 129, 144 A.2d 480, 482 (1958); Sigel Estate, 169 Pa. Super. 425, 429, 82 A.2d 309, 311 (1951). Several other cases, however, have called the statutes “dangerous." See, e.g., Myers Estate, 395 Pa. 459, 462, 150 A.2d 525, 526 (1959); Ryman's Case, 139 Pa. Super. 212, 223, 11 A.2d 677, 683 (1940).

${ }^{10}$ See note 123 infra \& accompanying text. 
This Comment is premised upon the assumption underlying all civil incompetency provisions: that guardianship is a necessary institution. ${ }^{11}$ To state the obvious case, it is desirable that courts be empowered to appoint a guardian of the estate of a person who suddenly loses all capacity to reason, where the incapacity causes the person hardship resulting from his inability to manage his property, and where no prior legal arrangement ${ }^{12}$ exists to cover this catastrophe.

That guardianship of a person's property is sometimes the only reasonable course does not mean, however, that it is to be embarked upon whenever a person seems to be having property-management problems. The consequences of guardianship are far too dire ${ }^{13}$ to be unleashed lightly. ${ }^{14}$ In Pennsylvania, the

11 For a contrary opinion see the remarks of Dr. Thomas Szasz in Current Comment, Symposium on the Aging Poor, 23 Syracuse L. Rev. 45, 82 (1972) (advocating "the immediate abolition of all involuntary psychiatric interventions imposed on the aged by the state").

${ }^{12}$ Several alternatives are available. Depending on the nature of the estate and the needs of the persons involved, the solution may lie in an inter vivos trust, in joint tenancy, in a power of attorney, or in some other estate planning device. See generally Allen, supra note 1, at 144-93; University of Miami Law Center, The Sixth Annual INSTitute on Estate Planning 19 72.1507-.1509 (1972); Corcoran, The Revocable, Irrevocable Living Trust for the Incompetent Client, 110 Trusts and Estates 96 (1971); Kalcheim, Legal Protection for the Aged, 20 Prac. Law., Dec. 1974, at 79.

${ }^{13}$ One study of guardianship based on interviews with professionals in the field concluded that "in spite of its protective features, appointment of a guardian is often regarded as an unattractive solution. In fact, many of the interviewees characterized it as a last resort, a course to be avoided if at all possible." Allen, supra note 1, at 150. Although this study did not encompass Pennsylvania, the objections it raises seem to apply with equal force to Pennsylvania guardianships.

${ }^{14}$ All too often, the mythical talisman, "preventative and protective," is summoned up to dispel the dark side of the deprivations of guardianship. See note 9 supra. One author has concluded that "the very structure of [guardianship] proceedings-as well as judicial adherence to the view that guardianship serves the ward's best interest and lack of sympathy for the unproductive elderly-may encourage a finding of incompetency." Comment, The Disguised Oppression of Involuntary Guardianship: Have the Elderly Freedom to Spend? 73 YALE L.J. 676, 684 (1964). Lawyers, too, are sometimes guilty of excessive casualness in this area. In one case, an attorney described how he managed to win a "simple custodianship of [the] property" of his client. The practitioner outlined the facts of the case of a man who had been committed to an institution by his family:

$[T]$ he great trouble was he was very generous. If some telephone operator was kind

to him, he would send her a big box of orchids, maybe 50 or 100 orchids.

He was spending a lot of money, but it was a trust fund of his own money, really. The family was afraid that he would dissipate what they would eventually inherit.

And really he was no harm to himself or society, a perfectly nice guy-just an aberration in this area.

So we brought the case to court and got him freed, just had a custodian appointed for his property. He is, as far as I know, still loose.

University of Miami Law Center, The Sixth Annual Institute on Estate Planning If 72.1502 (1972) (emphasis supplied). It is certainly commendable that the lawyer won freedom for his client, but to use the word "just" in speaking of involuntary guardian- 
incompetent must relinquish possession of his real and personal property to his guardian, ${ }^{15}$ who is empowered to "sell, at public or private sale, any personal property of the [incompetent]."16 The incompetent is "incapable of making any contract or gift or any instrument in writing ...."17 This provision may prevent an incompetent from legally marrying ${ }^{18}$ and from executing a valid will, ${ }^{19}$ as well as from forming enforceable business contracts and from making valid inter vivos gifts. An incompetent also loses the capacity to initiate lawsuits on his own. ${ }^{20}$ After a person has been declared incompetent, the burden shifts to him, in a petition for termination of the guardianship, ${ }^{21}$ to show that he has regained competence. ${ }^{22}$

Beyond the direct legal consequences, an incompetent may suffer severe social, commercial, and psychological effects. ${ }^{23} \mathrm{He}$

ship seems rather callous. It is likely that this gentleman derived pleasure, perhaps his greatest or only pleasure, from making unexpected gifts to telephone operators and others. To deprive him of the freedom to act on such impulses may well remove one of his reasons for living. This case is especially unsettling in light of the lawyer's acknowledgement that the motivation for the suit for commitment was to keep the potential heirs from losing their inheritance.

Finally, it is appropriate to follow the lead of another writer on guardianship in using the words of Justice Brandeis to point up a great danger in looking upon guardianship as "preventative and protective": "Experience should teach us to be most on our guard to protect liberty when the Government's purposes are beneficent. . . . The greatest dangers to liberty lurk in insidious encroachment by men of zeal, wellmeaning but without understanding." Olmstead v. United States, 277 U.S. 438, 479 (1928) (Brandeis, J., dissenting) (footnote omitted), quoted in Dershowitz, Psychiatry in the Legal Process: A Knife That Cuts Both Ways, 4 Trial, Feb./March 1968, at 29, 33.

${ }^{15}$ Pa. Consol. Stat. AnN. tit. 20, § 5521(1) (1975), incorporating the minors' estates provisions of $i d . \$ 5141$.

${ }^{16} I d . \S 5151$, incorporated by id. $\S 5521(22)$.

${ }^{17}$ Id. $\$ 5524$.

${ }^{18}$ One Pennsylvania court has stated that an incompetent's capacity to marry "may be open to serious question ...." Urquhart Estate, No. 344 of 1964, 21 la (Chester County Orphans' Ct., Nov. 16, 1966), rev'd on other grounds, 431 Pa. 134, 245 A.2d 14I (1968).

${ }^{19} \mathrm{~A}$ finding of incompetency before execution of a will raises a presumption that the will is invalid. This presumption "can only be overcome by satisfactory evidence of restoration of capacity." Hoffman's Estate, 209 Pa. 357, 360, 58 A. 665, 666 (1904); accord, Brennan's Estate, $312 \mathrm{~Pa} .335,339-40,168 \mathrm{~A} .25,26$ (1933). An adjudication of incompetency after execution of the will, however, may be given some weight as "proper evidence for consideration" in a will contest. Mulholland's Estate, $217 \mathrm{~Pa}$. 65, 68, 66 A. 150 (1907).

${ }^{20}$ See PA. R. Crv. P. 2051-64.

21 "The court, upon petition and after such notice as it shall direct, may find, after a hearing at which good cause is shown, that a person previously adjudged incompetent has become competent." Pa. Consol. Stat. AnN. tit. 20, §5517 (1975).

${ }^{22}$ In re Estate of Porter, 345 A.2d 171, 174 (Pa. 1975). The court noted, however, "that this is a much lighter burden than that upon those who seek to obtain an initial adjudication of incompetency ...." Id. at 174 n.6.

${ }^{23} \mathrm{~A}$ ruling that an individual lacks capacity in one area naturally raises the question as to the extent to which he may lack capacity in other areas. Conse- 
is told that he is unable to handle the estate he may have accumulated through years of hard work. It is not difficult to imagine the sense of despair, the loss of dignity, and the frustration that often must rage in the mind of one who is told that the state's "preventative and protective" law will now relieve him of the right to spend his own money freely.

In view of the drastic consequences of guardianship it is crucial, in order to prevent unwarranted deprivation of individual liberties, that the Commonwealth limit the imposition of involuntary guardianship to those for whom it is absolutely necessary. Whether the required limitation is presently embodied in the Pennsylvania incompetency standard, either by legislation or by judicial construction and application, is the subject of this Comment. ${ }^{24}$

\section{The Statutory Standard}

The Pennsylvania incompetency standard is found in section 5501 of the Decedents, Estates and Fiduciaries Code: ${ }^{25}$

\footnotetext{
quently, others may be chary of dealing with him. Lack of certainty about a person's competence may be as potent a deterrent as a determination of legal incapacity.

Frequently the loss-or the fear of loss-of the whole bundle of civil rights is more traumatic to the individual and his family than relinquishing financial control.
}

V. Lehmann \& G. Mathiasen, Guardianship and Protective Services for Older People 13 (1963). Indeed, it has been suggested that the dread of a stigmatizing public hearing on incompetency can be "so great that in many cases members of the family will go to extreme lengths to avoid such embarrassment." G. STEPHENson, supra note 5, at 87. Furthermore, "[ $t]$ he stigma of incompetency and the loss of civil rights may lead to further debilitation of an already marginally functioning person." Regan, supra note 5 , at 607 n.204.

${ }^{24}$ Although this Comment is limited in scope to the problems arising from the incompetency standard and its application, several other guardianship procedures must be thoroughly investigated if the Commonwealth is to assure its citizens that they will not involuntarily lose control of their property except upon a showing of a strict necessity and under carefully controlled procedures. Among the potential trouble areas are lack of adequate notice to the alleged incompetent; his possible absence from the hearing; denial of his right to effective counsel; improper choice of a guardian; excessive, or abused, powers of the guardian; burdensome procedures for terminating the guardianship; and improper accounting by the guardian. For a brief outline of some of these problems, see Regan, supra note 5, at 605-09.

${ }^{25}$ The current statutory definition of one who can be subjected to guardianship differs from the previous one in certain substantive respects. The succession of major changes in the definition of "incompetent" (excluding minor amendments) is as follows: so weak in mind, that he or she is utterly unable to take care of his or her property and is therefore liable to dissipate or lose the same and to become the victim of designing persons ....

Act No. 220, § 1, [1895] Pa. Laws 300 (repealed 1907). insane or feeble-minded or epileptic, or so mentally defective that he or she 
"Incompetent" means a person who, because of infirmities of old age, mental illness, mental deficiency or retardation, drug addiction or inebriety:

(1) is unable to manage his property, or is liable to dissipate it or become the victim of designing persons; or

(2) lacks sufficient capacity to make or communicate responsible decisions concerning his person. ${ }^{26}$

Section 5511 (a) effectuates this definition by providing that the court "may find a person ... . to be incompetent and appoint a guardian or guardians of his person or estate." 27

An ambiguity to be resolved at the outset is whether a finding of incompetency under either paragraph (1) or (2) justifies the appointment of a guardian of the estate. That paragraph (1) mentions the incompetent's "property" only, while paragraph (2) mentions only his "person," suggests that the former was intended to be the standard for appointment of a guardian of the estate and the latter the standard for appointment of a guardian of the person. This conclusion is supported by an examination of the Uniform Probate Code, which influenced the current Pennsylvania statute. ${ }^{28}$ The Code standard for appointment of a guardian of the person ${ }^{29}$ is quite similar to paragraph (2) of the Pennsylvania standard. That the Pennsylvania legislature did not

is unable to take care of his or her property, and in consequence thereof is liàble to dissipate or lose the same, and to become the victim of designing persons ....

Act No. 222, § 1, [1907] Pa. Laws 292 (repealed 1951).

a person, who, because of mental infirmities of old age, mental illness, mental deficiency, drug addiction or inebriety, is unable to manage his property, or is liable to dissipate it or become the victim of designing persons. It includes a person heretofore declared to be a lunatic, an habitual drunkard, insane or weak-minded.

Act No. 158, art. I, \$ 102(3) [1951] Pa. Laws 612 (repealed 1955).

a person who, because of mental infirmities of old age, mental illness, mental deficiency, drug addiction or inebriety, is unable to manage his property, or is liable to dissipate it or become the victim of designing persons.

Act No. 359, art. I, § 102(3) [1955] Pa. Laws 1154 (repealed 1974).

a person who, because of infirmities of old age, mental illness, mental deficiency or retardation, drug addiction or inebriety:

(1) is unable to manage his property, or is liable to dissipate it or become the victim of designing persons....

Pa. Consol. Stat. Ann. tit. 20, § 5501 (1975).

${ }^{26}$ Pa. Consol. Stat. Ann. tit. 20, § 5501 (1975).

${ }^{27}$ Id. § 5511 (a); see id. \$5511(b).

${ }^{28}$ See Nast, Probate, Estates and Fiduciaries Code, Fiduciary Rev., Jan. 1975, at 1.

${ }^{29}$ Uniform Probate Code $\$ \S 5-101,5-304$. 
add the words "or his property" to paragraph (2), which it could have done easily had it intended that a finding of incompetency under paragraph (2) justify appointment of a guardian of the estate, is strong evidence that the legislature intended the two paragraphs to be mutually exclusive in their application to guardianship of the estate and of the person. For these reasons, this Comment will consider only paragraph (1) of the statute as bearing on the appointment of a guardian of the estate.

\section{Analysis of the Pennsylvania INCOMPETENCY STANDARD}

In order to assess the effectiveness of the Pennsylvania statute in protecting against unwarranted deprivation of individual liberties, it is important to recognize that competing interests are involved. Absolute protection of individual liberties could be readily assured by having no guardianship procedure at all. But protection of individual liberties is not the sole objective. To be weighed against protection of individual liberties is society's desire to shield from catastrophe those whom it judges unable to protect themselves. It is submitted that these competing interests will be best harmonized by recognizing as the fundamental principle of guardianship law the proposition that a person cannot be deprived of control over his estate unless the court is satisfied that a guardianship is necessary for his benefit. ${ }^{30}$ This Comment will analyze how well the Pennsylvania statute effectuates this benefit principle.

For purposes of analysis, the Pennsylvania incompetency standard may be seen as a set of causes and a set of effects. To find a person incompetent a court must find in him one of the effects (unable to manage his property, liable to dissipate his property, or liable to become the victim of designing persons) as a result of one of the causes (infirmities of old age, mental illness, mental deficiency, retardation, drug addiction, or inebriety). The degree to which these required effects and causes implement the benefit principle is discussed below.

${ }^{30}$ The courts have generally recognized this proposition. See, e.g., In re Aronson, 1 Pa. D. \& C.2d 638, 639 (Montgomery County C.P. 1954); In re Palmer Estate, 99 Pitt. Legal J. 479, 483 (Allegheny County C.P. 1951). Even the state supreme court subscribed to this view when it pointed out that "[a] man may do what he pleases with his personal estate during his life. He may even beggar himself and his family if he chooses to commit such an act of folly. When he dies, and then only, do the rights of his heirs attach to his estate." Urquhart Estate, 431 Pa. 134, 135-36, 245 A.2d 141, 142 (1968) (quoting Bryden's Estate, 211 Pa. 633, 636, 61 A. 250, 251 (1905)). 


\section{A. The Causes}

Deprivation of the right of an individual of sound mind to dispose of his property as he chooses can never be for that person's benefit. A corollary to the benefit principle, therefore, is that a guardianship should not be imposed upon an individual, no matter how likely it is that his particular manner of managing his property will cause him hardship, unless the court is convinced that the individual has not voluntarily and in sound mind chosen to manage his property in that manner. ${ }^{31}$

Although the legislature has not explicitly recognized the benefit principle, it has made a step toward effectuating this corollary by establishing that a guardianship cannot be imposed simply because a person does not manage his property as would the court. The legislature has required that before a guardianship may be imposed, the individual's property management problems must result from one of several listed causes. This causation requirement will advance the benefit principle if the list of permissible causes is drawn and applied narrowly enough to exempt from the guardianship laws individuals who, in sound mind, have voluntarily chosen to manage their property in the allegedly incompetent manner. ${ }^{32}$ Whether the list of causes has been so drawn and applied is the subject of the following discussion.

\section{Infirmities of Old Age}

Although the first listed cause, "infirmities of old age," might be construed as a euphemism for senility, such was not the legislative intent. A more accurate construction is "mental or physical infirmities of old age." Prior to 1974 the statute listed "mental infirmities of old age" as a cause. ${ }^{33}$ The new version, which deleted the word "mental," "clearly includes ... those who are mentally sound but unable to care for themselves because of an accident or for any other reason."34

The legislature's decision to permit the appointment of a guardian of the estate of a nonconsenting elderly person who suffers from only physical infirmities undoubtedly was made with good intentions. The purposes were probably to reduce the stigma that attaches to a finding of incompetency, ${ }^{35}$ and to make

\footnotetext{
${ }^{31}$ See text accompanying note 82 infra.

${ }^{32}$ See text accompanying notes 65-79 infra.

${ }^{33}$ Note 25 supra.

${ }^{34}$ Current Legislation, Fiduciary Rev., Jan. 1975, at 4.

35 "As so defined the word 'incompetent' may have less stigma attached to it." Id.
} 
the court's protection of property available to a wider range of persons than in the past. ${ }^{36}$ Notwithstanding the nobility of the legislative intention, however, the advisability of adding physical infirmities to the causes of incompetence is subject to serious question. First, does the amended definition really achieve its purposes? Will an elderly person really be less stigmatized by the incompetency label simply because the determination may have been based on physical, rather than on mental difficulties? Common sense would indicate that the finding itself bears the stigma. How likely is it that one's neighbors and business associates are attuned to such subtleties as the omission of the word "mental" from one branch of the state's definition of "incompetent"? If reduction of stigma is a major purpose of the change, a more effective measure would be to change the label from "incompetent" to, for example, "protected person"37 or "conservatee," 38 or some other more neutral term. ${ }^{39}$

Second, one must question the advisability of widening the categories of persons for whom involuntary guardianship is "available." Of course, guardianship might be a very welcome solution to the property-management problems of, for example, a consenting quadraplegic whose mind is alert. ${ }^{40}$ But, to make physical incapacity a ground for involuntary guardianship is an unnecessarily broad and dangerous expansion of the definition of "incompetent."

It is difficult to conceive of a situation in which it would be desirable for a court to impose a guardianship on the estate of an unconsenting, physically disabled person. If such a person wants a guardian, he will consent. If he does not want a guard-

36 " $[\mathrm{T}]$ he amendment to the definition of incompetent may encourage a greater employment of guardianship where it can serve a purpose . . . " Frduciary Rev., Apr. 1975, at 4. The inclusion of physical incapacity as a ground for incompetency generally seems to have these two purposes. See, e.g., Regan, supra note 5, at 605; Comment, Guardianship of Property of Incompetents, 9 Real Prop. Prob. \& TrUSt J. 535, 542 (1974).

${ }^{37}$ See UNIform Probate Code \$ 5-101(3).

${ }^{38}$ See N.Y. Mental Hygiene Law $\$ 77.01$ (McKinney Supp. 1975).

${ }^{39}$ The term "incompetency" was condemned by one interviewee in an incompetency study as follows: "I would suggest abandoning the term 'competency.' If you tell someone he is incompetent, he is insulted, humiliated, and cannot accept it. On the other hand, you can often convince a patient that it is to his advantage to have someone made responsible for the protection of his person and property." AlleN, supra note 1, at 37.

The statutory revision proposed by this Comment, set forth in note 151 infra, replaces "incompetent" with "disabled person."

${ }^{40}$ See Grim Estate, 89 Montgomery County L. Rptr. 173 (Orphans' Ct. 1968) (decided under earlier statute in which the definition of "incompetent" did not include those with purely physical incapacities). 
ian, then either he has correctly concluded that he can manage his property without a guardian's assistance, ${ }^{41}$ or he has incorrectly, or foolishly, decided that he does not need such help. Only in the latter situation can an argument be made that the guardianship should be imposed involuntarily. If the decision is irrational, the person is conceivably suffering from a mental infirmity sufficient to permit adjudging him incompetent under the old standard. But, if the decision is merely foolish, the benefit principle would be violated by imposing an involuntary guardianship because, by hypothesis, the individual is of sound mind and has voluntarily chosen a method of property management. Non-disabled persons make foolish decisions about their property every day, without risking loss of its control. Why, then, should a person who is physically handicapped but mentally alert lose the right to make similar mistakes? ${ }^{42}$ In sum, the statute's purpose of making guardianship available to more persons is laudable, but the added protection of consent should be added where the disability is solely physical. ${ }^{43}$

Finally, the term "infirmities of old age" must be questioned for singling out "old age." If the missing consent requirement were added, "infirmities of old age" would not be an improper ground $^{44}$ for appointing a guardian; but still one is forced to ask what "old age" adds to the definition. If a young person and an old person suffer identical infirmities, should guardianship be available only to the old person?" ${ }^{45}$ If the statute is truly "preven-

41 "No matter how far a person may be incapacitated he can manage his property and care for himself by an agent or servants if his mind is unimpaired." MODEL Probate Code $\S 196$, Comment, quoted in Note, Guardianship in the Planned Estate, 45 Iowa L. Rev. 360, 367 n.45 (1960).

${ }^{42}$ See note 108 infra \& accompanying text.

${ }^{43}$ Such is now the law in some jurisdictions. For example, Ohio law provides: "If a person is incompetent due to physical disability, the consent of the incompetent must first be obtained before the appointment of a guardian for him ...." OHIO REv. CODE ANN. \$2111.02 (Anderson 1968). The statute permitting appointment of a guardian for an unconsenting, physically disabled person was held to violate the Ohio constitution in Schafer v. Haller, 108 Ohio St. 322, 140 N.E. 517 (1923). Cf. In re Guardianship of Irvine, 72 Ohio App. 405, 52 N.E.2d 536 (1943) (where the incapacity is purely physical, the consent of the incompetent must be given in writing in open court). But see In re Guardianship of Schmidt, 221 Ore. 535, 352 P.2d 152 (1960) (a guardian may constitutionally be appointed for a person who is physically incapacitated and incapable of managing his estate).

The statutory revision proposed by this Comment, set forth in note $15 \mathrm{I}$ infra, precludes involuntary imposition of a guardianship upon the estate of a person whose disability is purely physical.

${ }^{44}$ The unmodified phrase, "old age," has been criticized as a ground for incompetency where consent is not required. See Dewey, Civil Incompetency in Ohio: Determination and Effect, 34 U. Cin. L. Rev. 419, 423 (1965).

${ }_{45}$ There may be problems of constitutional dimension here. First, if one views 
tative and protective" in nature, ${ }^{46}$ the phrase "infirmities of old age" should be replaced by "mental or physical infirmities," provided that the requirement of consent is added when the infirmities are only physical. ${ }^{47}$

\section{Mental Illness, Mental Deficiency and Mental Retardation}

The next three causes listed-mental illness, mental deficiency, and mental retardation-do not share the defect of the "physical infirmities of old age" provision: A finding that an individual is mentally ill, or deficient, or retarded, and that such condition has caused what the court perceives to be an inability to manage his property, is strong evidence that the individual has not voluntarily and in sound mind chosen his course of management. It is doubtful that the legislature could accomplish the protection of voluntary choice with a narrower standard. The potential difficulty with these causes lies in their application.

In order to effectuate the benefit principle, the courts must adhere scrupulously to the requirement that a definite, debilitating mental illness, deficiency, or retardation be found before one is declared incompetent. Happily, the courts have properly applied this requirement.

In Myers Estate, ${ }^{48}$ for example, the state supreme court affirmed a finding of incompetence where the subject's own testimony had shown him to be "forgetful, disoriented, confused

guardianship as "good for" the incompetent, it must be asked why it should be made available only to those who suffer from "infirmities" and are "old." If it is because the young may recover, that does not explain the disparity of treatment: when recovery comes, the guardianship can be terminated. The more important question arises, however, when one takes the realistic approach that guardianship is a last resort with attendant oppressive consequences for the incompetent. Then it must be asked why an "old" person must suffer those consequences, whereas a "young" person with identical infirmities need not suffer them. Although age has not yet been recognized as a "suspect classification" for federal equal protection purposes, the immutability of old age and the stigma currently associated with it are two factors that suggest that it should be on a par with race, alienage, and national origin. For a discussion of the constitutional implications of classifications based on old age, see Debate Between H. Eglit and L. Waldman \& N. Levine, Is Compulsory Retirement Constitutional? 1 Crv. Lib. Rev., Fall 1974, at 87.

${ }^{46}$ See note 9 supra \& accompanying text.

47 The statutory revision proposed by this Comment, set forth in note 151 infra, incorporates this suggested modification.

At least one state has abandoned all specific requirements that any particular infirmities, mental or physical, be found: "An incompetent is a person judicially declared to be incapable of managing his affairs." N.Y. EsT., Powers \& TRUSTs LAw § 1-2.9 (McKinney 1967). Presumably, however, the word "incapable" in this statute must be construed to include some element of mental incapacity.

${ }^{48} 395 \mathrm{~Pa} .459,150$ A.2d 525 (1959). 
and ... susceptible to suggestion ...."49 The testimony of the 83-year-old Dr. Myers indicated his failure to recognize his own doctor, to remember signing a trust agreement, and to remember the names of his attorneys. Other mental lapses were evidenced by his behavior in court and on the witness stand.50 Although the trial court's observation of Dr. Myers was "fortified by the opinions of two disinterested and qualified physicians," 51 the supreme court noted that "[b]y far the most significant evidence of record is Dr. Myers own testimony." ${ }^{2}$ The trial court obviously based its finding of lack of mental capacity on substantial relevant evidence. By following this example the courts can help to implement the benefit principle and thereby protect individual liberties from unwarranted intrusions. ${ }^{53}$ Nevertheless, the danger of mistake in borderline cases makes it desirable for the courts to require, rather than merely permit, the testimony of disinterested psychiatrists on the issue of mental condition. ${ }^{54}$

The third cause in the "mental" trilogy, retardation, probably did not need to be added to the definition. ${ }^{55}$ This ground may have been added because of cases such as In re Ferraro, ${ }^{56}$ where a petition for guardianship was denied, the court noting a physician's testimony that the subject was "retarded, rather than incompetent." 7 Later, however, the court more correctly described the situation: "[W]e find no proof that she is retarded to the degree of incompetence." 58 Furthermore, the court noted that the alleged incompetent "is regularly employed, manages

$49 \mathrm{Id}$. at $468, \mathrm{I} 50 \mathrm{~A} .2 \mathrm{~d}$ at 529 .

${ }^{50} \mathrm{Id}$. at $467-68,150 \mathrm{~A} .2 \mathrm{~d}$ at 529 .

51 Id. at 468,150 A.2d at 529 .

${ }^{52} I d$. at 467,150 A.2d at 528 .

${ }^{53}$ For other cases where the courts have based their findings of incompetency on the proper quality of evidence of mental trouble, see Refior Case, 160 Pa. Super. 305, 50 A.2d 523 (1947); Arthur's Case, 136 Pa. Super. 261, 7 A.2d 55 (1939); In re Estate of Ochs, 27 Northumberland L.J. 131 (C.P. 1955).

54 See Comment, supra note 14, at 685-86. The proper role of psychiatric testimony in incompetency proceedings is a matter of some debate. One author has concluded that psychiatrists really serve a para-legal function, that their medical training does not contribute significantly to their ability to diagnose mental problems, and that their usefulness as expert witnesses at competency hearings should therefore be questioned. Leifer, The Competence of the Psychiatrist to Assist in the Determination of Incompetency: A Sceptical Inquiry into the Courtroom Functions of Psychiatrists, 14 SYracuse L. Rev. 564 (1963). For a more appreciative view of the role of psychiatrists see Mezer \& Rheingold, The Role of the Psychiatrist in Mental Competency Cases, 9 Prac. LAw, Jan. 1963, at 85.

${ }^{55}$ Retardation was added to the definition by the 1974 amendment. See note 25 supra.

56 63 Berks County L. J. 177 (C.P. 1972).

${ }^{57} \mathrm{Id}$. at 179 .

${ }^{38} \mathrm{Id}$. at 180 . 
her own affairs within her limitations and saves her money. She is in no danger of dissipating or losing any of it." 59 The facts of this case did not justify declaring this person incompetent, whether or not retardation was included in the statutory definition. If a retarded person does have such mental and functional problems as to require a guardian, his situation can be dealt with adequately by the general statutory standard. The danger always exists that if new categories such as this are added, they may sweep in persons who come within their description, but who do not strictly meet the general standards. If the addition of retardation as a ground means that the allged incompetent in Ferraro would have been declared incompetent, the ground should be dropped from the statute. ${ }^{60}$

\section{Drug Addiction and Inebriety}

The last two causes listed, drug addiction and inebriety, present a curious problem. No Pennsylvania case has based a finding of incompetency on either of these grounds, and similar non-use of such provisions seems to be the norm in at least one other jurisdiction. ${ }^{61}$ Certainly, if alcohol or drugs so affect a person's mind that he loses his power of rational choice, intervention would be justified even without these statutory causes because the individual would likely fall within one of the "mental" categories. ${ }^{62}$ However, declaring a person incompetent because of property-management problems caused solely by alcohol or drug abuse, with no intermediate finding of mental disorder, would violate the benefit principle for the same reasons as would a finding of incompetency based on a physical disability alone. ${ }^{63} \mathrm{~A}$ person of sound mind who voluntarily chooses to drink or take drugs, and consequently mismanages

\footnotetext{
${ }^{59} I d$.

${ }^{60}$ The statutory revision proposed by this Comment, set forth in note 151 infra, deletes retardation as a separate ground for incompetence.

${ }^{61}$ A study of incompetency in the District of Columbia reported that no cases had been found arising under the alcoholism or drug addiction provisions of the statute in that jurisdiction. Alles, supra note 1, at 202.

${ }_{62}$ One study found that

[t]he view was frequently expressed by psychiatrists and psychologists that chronic alcoholism may exist which is not accompanied by brain damage and that this does not result in incompetency ... . Thus, a finding of incompetency based on alcoholism without a finding of mental disability would appear to be subject to the same objection as a finding, without consent, based on physical disability.

Dewey, supra note 44 , at 423-24 (footnote omitted).

${ }^{63}$ See notes 40-43 supra \& accompanying text.
} 
his property, should no more be declared incompetent than should a person who directly chooses, out of laziness or indifference, to let his affairs go to ruin. Neither suffers from the inability to make a rational choice which alone justifies the conclusion that a guardianship would be to the individual's benefit. Inclusion of drug addiction and inebriety in the statute, therefore, serves no valid purpose. ${ }^{64}$

\section{The Requirement of a Causal Link}

The mere concurrence of one of the statutory "causes" and one of the statutory property-management "effects" is not, of course, sufficient to justify imposing a guardianship under the benefit principle. In the absence of a direct causal relationship between the two findings, the coincidence of a statutory "cause" and "effect" gives no more justification for state interference than where a mentally fit person is unable to manage his own affairs. The language of the statute itself requires that the perceived inability to manage property be "because of" a specified statutory condition. ${ }^{65}$

Some reported opinions raise concern, however, that this basic causal requirement may be overlooked by judges who are presented with evidence that an alleged incompetent is unable to manage his property and with evidence that the alleged incompetent is mentally ill, mentally deficient, or retarded. In Sigel Estate, ${ }^{66}$ for example, the evidence quite clearly established that Mrs. Sigel was suffering from an acute paranoid psychosis that caused her to believe she was being pursued by killers with atomic rays, and to protect herself by lining the windows of her house with lead sheets and by buying a geiger counter to detect the rays' presence. Although the analysis is clouded somewhat because the alleged "effect" was the nebulous "victim of designing persons" provision, ${ }^{67}$ the court did not articulate adequate reasons for concluding that the mental illness-the delusions Mrs. Sigel was suffering-would cause Mrs. Sigel to become the victim of designing persons.

Victimization by designing persons must mean something more than merely spending money on "unneeded" items; otherwise nearly everyone would fit within the category. Yet the

${ }^{64}$ The statutory revision proposed by this Comment, set forth in note 151 infra, deletes drug addiction and inebriety as independent grounds for incompetence.

${ }^{65}$ Text accompanying note 26 supra.

${ }_{66}^{66} 169$ Pa. Super. 425, 82 A.2d 309 (1951).

${ }^{67}$ See text accompanying notes 113-19 infra. 
court made no finding of a mental problem affecting Mrs. Sigel's capacity to handle money, to remember past business dealings, to deal at arm's length, or to distinguish designing persons from others and consequently avoid the designing ones. There was no evidence that she would waste an undue amount of money on protective items, or that she would purchase them, if at all, from other than reputable, non-"designing" persons. In the absence of such evidence it is hard to see a causal link between Mrs. Sigel's conceded mental problem and the likelihood she would become the "victim" of designing persons.

The finding of a causal link between a perceived mental condition and a perceived property-management problem is essential in order to protect against unjustified deprivations of individual liberties resulting from imposition of guardianships where the link is not present. The problem suggested by Sigel Estate could be averted by amending the statute to require a more definite causal link-one that is not likely to be overlooked by the courts, and one that requires a definite finding that a mental problem actually and substantially affects processes bearing upon the alleged incompetent's property-management ability.

One solution would be for the statutory provision for the appointment of a guardian of the estate to incorporate a formulation analogous to the Model Penal Code provision on the mental defect that amounts to lack of legal responsibility. ${ }^{68}$ The following suggested addition to section 5511 of the Decedents, Estates and Fiduciaries Code, ${ }^{69}$ the provision empowering a court to appoint a guardian for the estate of an "incompetent," emphasizes the causal link requirement:

Provided that no person's estate shall be placed under guardianship without his consent unless at the time of the hearing as a result of mental infirmities, mental illness, or mental deficiency he lacks substantial capacity either to appreciate the harmful character of his conduct or to conform his conduct to the requirements of his own well-being. ${ }^{70}$

68 "A person is not responsible for criminal conduct if at the time of such conduct as a result of mental disease or defect he lacks substantial capacity either to appreciate the criminality of his conduct or to conform his conduct to the requirements of the law." Model Penal Code \$ 4.01(1) (Proposed Official Draft 1962).

69 Pa. Consol. Stat. ANn. tit. 20, § 5511 (1975).

${ }^{70} \mathrm{~A}$ proposed revision of sections 5501 and 5511 of the Decedents, Estates and Fiduciaries Code, PA. Consol. STat. ANN. tit. 20, $\$ \S 5501,5511$ (1975), incorporating all the changes recommended in this Comment, is set forth in full in note 151 infra. 
The American Law Institute formulation for criminal responsibility ${ }^{71}$ was adopted by the Court of Appeals for the District of Columbia Circuit in United States v. Brawner. ${ }^{72}$ Judge Leventhal discussed at length the problem of ascertaining legal responsibility where the defendant is mentally afflicted. He noted the conflict between the need for expert medical testimony and the "hazards in allowing experts to testify in precisely or even substantially the terms of the ultimate issue . ..,73 The opinion pointed out the need for the court "to see to it that the jury in an insanity case is informed of the expert's underlying reasons and approach, and is not confronted with ultimate opinions on a take-it-or-leave-it basis." 74 The court's concern that the question of causality be directly and fully explained is evidenced by its decision to "permit testimony by the expert, and cross-examination, on the causal relationship between the mental disease and the existence of substantial capacity for control (and knowledge) ...."75 The experts are to testify on the existence of mental illness and on causality, but not on the ultimate issue of legal responsibility, because the ultimate issue has ethical and moral implications which the factfinder must decide. Otherwise, the factfinder may be "influenced significantly by . . . testimony of expert witnesses really reflecting ethical and legal judgments rather than a conclusion within the witnesses' particular expertise."76

${ }^{71}$ Note 68 supra.

72471 F.2d 969 (D.C. Cir. 1972) (en banc).

${ }^{73} \mathrm{Id}$. at 979 (quoting Blocker v. United States, 288 F.2d 853, 863 (D.C. Cir. 1961) (en banc)).

${ }^{74}$ Id. at 1006. See generally Leifer, supra note 86. Dr. Thomas Szasz takes a more radical view of the role of psychiatrists in this area than does Dr. Leifer:

[S]o long as we allow doctors to play a leading role in the involuntary psychiatric management of others, ... we can expect only tragedies .... The first thing we should do is get rid of the doctors. The problem of dealing with the aged is a commonsense social problem; it is not a medical problem ....

Current Comment, supra note 11 , at 84 . Professor Dershowitz takes a similar view:

$[N]$ o legal rule should ever be phrased in medical terms; . . . no legal decision should ever be turned over to the psychiatrist; . . . there is no such thing as a legal issue which cannot-and should not-be phrased in'terms familiar to lawyers. And civil commitment of the mentally ill . . . is a legal issue. Whenever compulsion is used or freedom denied ... the issue becomes a legal one, and lawyers must be quick to immerse themselves in it.

Dershowitz, The Law of Dangerousness: Some Fictions About Predictions, 23 J. Legal Ed. 24, $47(1970)$. For a more appreciative view of the role of psychiatrists, see Mezer \& Rheingold, supra note 54 , at 85 .

75471 F.2d at 1006-07.

${ }^{76}$ Id. at 983. In Commonwealth ex rel. Finken v. Roop, 234 Pa. Super. 155, 339 A.2d 764, the court criticized a civil commitment statute which "has asked too much of 
The Brawner solution would be an apt one in the incompetency context. If a person with no mental defect causally related to capacity to appreciate the criminality of his conduct is responsible enough to be convicted of a crime, then one with no mental defect causally related to his apparent inability to manage property is responsible enough to retain control over his property and to suffer the consequences. Management of one's own property may have the stature of a "fundamental right." 77 In another context, Justice Brennan noted the finding by 49 states that eighteen-year-olds are criminally responsible for their actions, and reasoned that they should not be denied the fundamental right to vote, because "differences in maturity and intelligence between 18-year-olds and persons 21 years of age and over are [found to be] too trivial to warrant specialized treatment for any of the former class in the critically important matter of criminal responsibility."78 Likewise, if one is found to possess the requisite mental capacity to be responsible for his criminal acts, he should not be deprived of the important right to manage his own affairs. Furthermore, adopting the Brawner standard for this area would have an additional positive effect. Psychiatrists would probably be less likely to disagree with each other than they presently $\mathrm{do}^{79}$ if opinions were restricted to the existence of a mental defect and its causal relationship to inability to manage property; the external, non-medical judgments as to desirability of guardianship would be less likely to enter into their testimony.

\section{B. The Effects}

\section{Unable to Manage His Property}

The first of the three statutory effects, a finding of one of which is a condition precedent to appointment of a guardian, is that an individual be "unable to manage his property." In requir-

psychiatrists. The psychiatrist is not merely asked to report his diagnosis and evaluation to the court, he is asked to draw legal conclusions-is the subject mentally ill and does he need confinement? These conclusions have severe legal consequences and should be answered by the judicial system." Id. at $182,339 \mathrm{~A} .2 \mathrm{~d}$ at 778 .

${ }^{77}$ See Jones v. Mayer Co., 392 U.S. 409, 441 (1968).

${ }^{78}$ Oregon v. Mitchell, 400 U.S. 112, 243 (1970) (opinion of Brennan, J.) (footnote omitted).

79 "[I]n the great majority of cases psychiatrists of equal qualification and experience will reach diametrically opposed conclusions on the same behavioral evidence." Faber v. Sweet Style Mfg. Corp., 40 Misc. 2d 212, 216, 242 N.Y.S.2d 763, 768 (Sup. Ct. 1963). But see Comment, "Civil Insanity": The New York Treatment of the Issue of Mental Incapacity in Non-Criminal Cases, 44 CoRNell L.Q. 76 (1958). 
ing an inability to manage property as opposed to a mere failure to handle it properly, the statute makes clear that individuals who mismanage their property because of laziness, indifference, or some other voluntary force are outside the scope of the law. The inability requirement, if properly applied, should protect against unwarranted invasions of individual liberties.

If guardianship law is to conform to the benefit principle, ${ }^{80}$ appointment of a guardian must be preceded by a determination that the individual will be better off with a guardian than he would be without one. This determination must inevitably involve a balancing process, because the imposition of a guardianship will ordinarily make the individual worse off in some respects than he would otherwise be, due to its severe social and psychological effects. ${ }^{81}$ Absent the consent of the alleged incompetent, the fact that a guardianship will place his property in more capable hands is not sufficient to outweigh the psychological costs of guardianship. Rather, to establish the requisite net benefit it must be shown that absent a guardianship the alleged incompetent will suffer actual hardship significant enough to outweigh the social and psychological harm likely to accrue from imposition of the guardianship. Only then can it be said that the guardianship is imposed for the benefit of the alleged incompetent.

A second corollary to the benefit principle emerges from this discussion: ${ }^{82}$ A guardian should be appointed only upon a finding of a significant potentiality of actual hardship to the alleged incompetent in the absence of a guardian. The Pennsylvania statute contains no explicit hardship requirement, and at times the courts have not been sufficiently vigilant in insisting upon a showing of hardship before imposing a guardianship. The alleged incompetent's management derelictions often have been of a minor sort, and have been seized upon to fill in the statutorily required element of effect.

For example, an examination of the opinion affirming a declaration of incompetency in Coulter Estate ${ }^{83}$ reveals that the only evidence of inability to manage property was: (1) that $\mathrm{Mr}$. Coulter had previously requested a guardian, at that time averring that he was unable to manage his property; and (2) a letter in evidence indicating that the director of his nursing home had

\footnotetext{
${ }^{80}$ See text accompanying note 30 supra.

${ }^{81}$ See note 23 supra \& accompanying text.

${ }^{82}$ See text accompanying note 31 supra.

${ }^{83} 406 \mathrm{~Pa} .402,178$ A.2d 742 (1962).
} 
influenced Mr. Coulter "in connection with the disposition of certain property ...." 84 The first bit of evidence should not be persuasive at the time of trial: ${ }^{85} \mathrm{Mr}$. Coulter would not have contested the petition if he had wanted the guardianship imposed at that time. The second item of evidence is very thin as well. That Mr. Coulter had been influenced to dispose of some unspecified quantity of property is totally lacking in weight. By that standard, anyone who yields to a salesman's pitch or to a charity's urgings could be called incompetent.

The courts have often reached more justifiable results, however. In In re Estate of Ochs, ${ }^{86}$ a guardianship was imposed on the estate of a woman who would buy excessive amounts of food, only to let it spoil; would lose money; and did not know whether rent due her had been paid. These deficiencies are extraordinary, and their continuance could clearly lead to hardship for the alleged incompetent. The petition was properly granted. In Refior Case $^{87}$ a man was declared incompetent who "could not conduct or understand small and ordinary business affairs, such as the bills rendered for his meals, or use of the telephone, etc." ${ }^{88}$ Again, such problems show a concrete need for guardianship. When a person cannot understand the simplest business affairs, because of a mental problem, the state justifiably may interfere on his behalf to prevent the financial and physical disaster that clearly could befall him under the circumstances. In Colt's Case ${ }^{89}$ the alleged incompetent "had transferred the whole of his personal property, recently acquired by inheritance, in exchange for an interest in a manufacturing corporation of which he had no knowledge whatever. He knew neither the value of the stock he was to receive, how much he was to get, nor how much he was to pay for it."90 In Quinn Estate ${ }^{91}$ there was evidence that Ms. Quinn made no attempt to clean up her house; that she often unjustifiably denied having received her welfare checks; that the house's plumbing was inoperative; and that she had several sets of outstanding bills that she was apparently planning to ignore.

${ }^{84} \mathrm{Id}$. at $409,178 \mathrm{~A} .2 \mathrm{~d}$ at $745-46$.

${ }^{85}$ The operative time for gauging competency is the time of trial, although evidence of conduct prior to trial is relevant. See, e.g., Hudak Appeal, 170 Pa. Super. 74, 77,84 A.2d 226, 228 (1951).

8627 Northumberland Legal J. 131 (C.P. 1955).

87160 Pa. Super. 305, 50 A.2d 523 (1947).

${ }^{88} \mathrm{Id}$. at $313,50 \mathrm{~A} .2 \mathrm{~d}$ at 527.

89215 Pa. 333, 64 A. 597 (1906).

${ }^{30} I d$. at $335,64 \mathrm{~A}$. at 598 .

9154 Pa. D. \& C.2d 405 (Phila. County Orphans' Ct. 1971). 
One is left, then, with two sets of cases-one where the inability to manage property, in conjunction with the requisite lack of mental capacity and causal link, justifies a declaration of incompetency, and another where it does not. The problem is to distill a viable, objective guideline for the courts to follow so that they will always reach a proper result, and never interfere with the property rights of those who actually manage their property adequately.

If the approach used is to define, or categorize, the types or degrees of property-handling derelictions that will justify involuntary guardianship, the task seems impossible, short of placing the alleged incompetent in a program that can measure his property-handling ability by directly observed, objective standards. ${ }^{92}$ A more fruitful approach is to realize that it is not the abstract inability to manage property but rather the effect of that inability, which is the evil sought to be cured by the statute. A person may be a blithering, drunken idiot who doesn't know a dollar bill from a Kleenex; but, if his economic needs are being adequately satisfied, he should be permitted to blither in unmolested bliss. ${ }^{93}$

It is, therefore, suggested that the statutory definition be narrowed, not by altering the "unable to manage property" standard, but by requiring, in the absence of informed, effective consent by the alleged incompetent, that the court not impose a guardianship unless it finds that the alleged incompetent will suffer actual hardship if no guardian is appointed.

For several possible reasons a person may be technically incompetent but still may not need a guardian of his estate. He may have little or no property in his estate. His property may be protected by a spendthrift trust. He may have an agent who has been handling his affairs adequately. His property problems may not be such as will ever cause him any hardship.

Two of these factors were present in Ex parte $v$. Gunn, ${ }^{94}$ where the court noted the existence of a spendthrift trust, and observed that, "at the present time [the alleged incompetent] seems entirely capable of managing this comparatively small sum of money ...."95 The court realized the potentially dangerous

${ }^{92}$ For an example of a program that does directly gauge and supervise recovery of property-handling ability, see the description of the Veterans Administration program in ALLEN, supra note 1, at 129-42. See also In re Kloman, 315 A.2d 830 (Mun. App. D.C. 1974).

${ }^{93}$ See notes 106-12 infra \& accompanying text.

9465 Montgomery County L. Rptr. 167 (C.P. 1949).

${ }^{95} I d$. at 168 . The sum involved ranged from $\$ 1,200$ to $\$ 1,500$ per year. 
nature of the law, and was unwilling to impose guardianship where it was not needed. Similarly in In re Aronson, ${ }^{96}$ in which the court declined to issue a decree of incompetency, no substantial amount of property was in danger. The Aronson court stated a principle that is fundamental in guardianship cases, but is too often ignored:

To take from an individual the control of his or her property is a high-handed and drastic thing to do and . . . it should not be done unless the court is wellsatisfied that it is necessary for the benefit of the alleged incompetent and the preservation of his or her estate. ${ }^{97}$

A third factor-the existence of an agent to handle the subject's affairs-led the court in Korell Estate ${ }^{98}$ to conclude that there was "no real and sufficient purpose"99 to declare the subject incompetent, because a trustee was already handling his affairs adequately. In Streda Estate ${ }^{\mathbf{1 0 0}}$ the court dismissed the petition, noting as one factor bearing on its decision that the alleged incompetent "expressed confidence that his wife was well able to handle all financial transactions on his behalf . . ."101 In Denner $v$. Beyer, ${ }^{102}$ although the court based its decision upon petitioner's failure to prove mental incapacity, a competent person was exercising a power of attorney on behalf of the alleged incompetent. A court should be required to determine whether such an arrangement exists; if it does, then normally a guardian need not be appointed.

One apparent problem with respect to such a delegation of business responsibility was addressed in Wood Appeal: ${ }^{103}$

[T]o conclude, from the fact that Mrs. Dean has delegated the conduct of all her important business affairs to others, that she does not need a guardian of her estate, is to beg the basic question involved, because unless she has mental capacity to manage her affairs herself she lacks the ability to appoint agents to do it for her. The derived authority in her agents cannot mount

${ }^{96}$ I Pa. D. \& C.2d 638 (Montgomery County C.P. 1954).

${ }^{97} \mathrm{Id}$. at 639 .

${ }^{98} 49$ Pa. D. \& C.2d 318 (Bucks County Orphans' Ct. 1970).

${ }^{99}$ Id. at 320.

10012 Pa. D. \& C.2d 523 (Delaware County Orphans' Ct. 1957).

101 Id. at 525.

102352 Pa. 386, 42 A.2d 747 (1945).

${ }^{103} 167 \mathrm{~Pa}$. Super. 92, 74 A.2d 528 (1950). 


\section{higher than her capacity to delegate such authority to them. ${ }^{104}$}

This problem should not be relevant to determining whether a guardian should be appointed. First, the statutory definition requires an effect-an inability to manage one's estate, or at least a likelihood of dissipation or victimization. If a competent agent were handling the alleged incompetent's affairs, such a showing presumably could not be made and the principal would not, therefore, be legally incompetent. Even if the agent did not have legal authority to act, as long as he acted in fact, the principal's affairs would be handled adequately, and guardianship would not be justified. If the agent ceased to act, then guardianship might become justified if no other equivalent arrangement could be established. The main point is that appointment of a guardian should not turn on the legal authority of the agent to act. ${ }^{105}$ In the case of a spendthrift trust or a power of attorney created before incompetency, and expressly designed to survive during incompetency of the principal, no such problems arise.

In light of these less drastic alternatives to guardianship, a court should, as some have done on their own initiative, construe the incompetency standard to require a showing that the alleged incompetent is unable to manage his property and is unable to have his property adequately managed for him. A court should inquire whether the person's property is being managed properly so as to meet the alleged incompetent's needs, but should not concern itself with who is doing the managing. Many

${ }^{104}$ Id. at 100,74 A.2d:at 541.

105 See University of Miami Law Center, The Sixth Annual Institute on Estate Planning I 72.1507 (1972) (remarks of Mr. Wormser of the New York Bar, moderator of the panel discussion on planning for protection of incompetents): "I suppose from one point of view the minute you are truly incompetent the power [of attorney] is no good, but banks seem to rely on the fact that you aren't incompetent until you are declared so."

A 1974 statute may remove the danger that an attorney-in-fact in Pennsylvania will be found to have exceeded his authority in such a situation. The new law provides:

The death, disability, or incompetence of any principal who has executed a power of attorney in writing, shall not revoke or terminate the agency as to the attorney in fact, agent or other person who, without actual knowledge of the death, disability, or incompetency of the principal, acts in good faith in reliance upon the power of attorney or agency. Any action so taken, unless otherwise invalid or unenforceable, shall bind the principal and his heirs, legatees, devisees, and personal representative.

PA. Consol. Stat. Ans. tit. 20, $\$$ 5602(a) (1975). Although it is not entirely clear whether "incompetence" means actual incompetence or adjudicated incompetence, it is urged that the latter should be the proper reading. 
perfectly competent persons use agents for convenience; they are not thereby considered incompetent, or unable to manage their property. The method of management they have chosen happens to be the use of an agent. A mentally ill person whose property is being adequately managed by an agent is, indeed, able to "manage" his own affairs.

One court has noted that "[t]he sole objective of the [guardianship] proceedings is the preservation of the estate for the ward and for no one else...".106 If that is not in fact the case, it certainly should be. The estate involved, by definition, belongs to the ward. Instituting guardianship proceedings to protect the interest of his prospective heirs, or of any other potential recipient, cannot be justified. ${ }^{107}$ If the alleged incompetent will not actually hurt himself, he should not be deprived of control of his property. He should be permitted to exercise his "right of foolishness,"108 a right that every competent person enjoys. If an elderly man derives pleasure from surprising perfect strangers with exotic gifts, or from accumulating a collection of undistinguished tubas, or from financing studies to prove the earth is shaped like a toothbrush, he may be deriving real satisfaction from his estate. Perhaps he feels no need to save for the future-that he is justified in acting out a long-suppressed dream. Entering his last years of life, he may care less about the mundane matters of "sensible" property management. He may wish to "live a little" while there is time. ${ }^{109}$ Whatever the motivation for his late-blooming extravagance, the standard of incompetency should include the requirement of a finding that he will be harmed if no guardian is appointed. If his "foolish" spending habits leave him with sufficient funds to live adequately, he should be left alone. The only relevant value is the welfare of the alleged incompetent. Society may despise wastefulness, but it should sooner condemn infringements on personal liberty.

${ }^{106}$ In re Palmer Estate, 99 Pitt. Legal J. 479, 488 (Allegheny County C.P. 1951).

${ }^{107}$ It might be argued that proceedings are justified where the subject's incompetent property management may deprive his dependents of adequate support, but there are sanctions against such derelictions in support law. If the dependents are being deprived, the state should use its support machinery to require payments, just as it would against a competent person. It is not necessary to give the state the added weapon of incompetency proceedings in such cases.

${ }_{108}$ One recommendation of a symposium on these problems was that "[ [] he proposed statute should seek to preserve the right of foolishness to the same extent as it is reserved to the rest of us not so unfortunate as to be labeled senile or mentally ill." Current Comment, supra note 11 , at 77.

${ }^{109}$ See Comment, supra note 14 , at 682. 
The statutory standard of incompetency should be amended to incorporate the idea that it is the ultimate effect on the alleged incompetent's ability to live adequately and comfortably that is crucial, not some abstract, elusive measure of his ability to manage property. The following provision should be added to the amending language to section 5511 of the Decedents, Estates and Fiduciaries Code, ${ }^{110}$ proposed above: ${ }^{11}$

And provided further that no person's estate shall be placed under guardianship without his consent unless his inability to manage his property is of such a nature and degree that substantial harm will befall him as a direct result of such inability, and unless no other suitable property-management arrangement to which he will consent is available. ${ }^{12}$

This standard would permit a court to follow existing precedents with respect to the issue of inability to manage property, but would diminish the danger of unnecessarily imposing a guardian on an alleged incompetent by requiring a finding of actual hardship. A court probably could not find actual hardship without first finding an inability to manage property. This modified formulation of the first "effect" standard-inability to manage property-would be acceptable.

\section{Likelihood of Dissipation or Victimization}

The second and third of the three effects upon a finding of one of which the statute permits the appointment of a guardian are that the individual is liable to (1) dissipate his property, or (2) become the victim of designing persons. These effects are unacceptable as components of a statutory definition of "incompetent."

First, these effects present a serious problem of reliable proof. The statute on its face does not require a showing of past dissipations of property but only a finding that one is "liable" to spend his capital down to nothing. ${ }^{113}$ It is difficult to imagine a

110 Pa. Consol. Stat. AnN. tit. 20, § 5511 (1975).

${ }^{111}$ Text accompanying note 70 supra.

112 A proposed revision of sections 5501 and 5511 of the Decedents, Estates and Fiduciaries Code, PA. Consol. Stat. ANN. tit. 20, $\$ \$ 5501,5511$ (1975), incorporating all the changes recommended in this Comment, is set forth in full in note 151 infra.

113 Nor have the courts read such a requirement into the statute. See Arthur's Case, 136 Pa. Super. 261, 264, 7 A.2d 55, 56-57 (1939). 
case in which it could be proved satisfactorily that a person who has never in the past dissipated his property is, at the time of trial, 114 "liable" to do so in the future. Apart from the common sense judgment of the factfinder, the only source of information on the likelihood of future dissipation or victimization appears to be the expert testimony of psychiatrists. However, if psychiatric testimony regarding past behavior is normally subject to question because of conflicting opinions and other weaknesses, ${ }^{115}$ its accuracy is even more questionable where predictions of future behavior are involved. ${ }^{116}$

Even if the doubtful accuracy of such predictions is overlooked, the question remains whether these two grounds are useful additions to the incompetency definition. These standards would be superfluous except in cases in which the alleged incompetent is able to manage his property, but, at the same time, is liable to dissipate it or to be victimized. Such cases might be imagined, if inability to manage property is construed so narrowly as to exclude both of the other two failings. No reason appears, however, so to construe the property management standard. It would be preferable to eliminate the latter two grounds, and to read them into the broad standard of inability to manage property. In that way, likelihood of dissipation or victimization would be relevant to showing inability to manage property, but would not be independent grounds for incompetence. This result would lessen the danger that the incompetency net would be widened to include persons who are, in fact, able to manage their property. ${ }^{117}$ Even though such cases might rarely

114 See note 85 supra.

115 See notes $74 \& 79$ supra.

116 In the context of psychiatric predictions of violent behavior prior to civil commitment, Professor Dershowitz' thorough survey of the relevant literature strongly suggested that

psychiatrists are rather inaccurate predictors; inaccurate in an absolute sense, and even less accurate when compared with other professionals, such as psychologists, social workers and correctional officials, and when compared to actuarial devices, such as prediction or experience tables. Even more significant for legal purposes: it seems that psychiatrists are particularly prone to one type of error-overprediction. In other words, they tend to predict antisocial conduct in many instances where it would not, in fact, occur.

Dershowitz, supra note 74, at 46. See also Ennis \& Litwack, Psychiatry and the Presumption of Expertise: Flipping Coins in the Courtroom, 62 CALIF. L. REv. 693 (1974). A Pennsylvania court recently observed, in the context of civil commitment, that "[i]n light of the difficulty of predicting that a given mental state is likely to result in future antisocial conduct, it seems necessary to require the commission of some overt act." Commonwealth ex rel. Finken v. Roop, 234 Pa. Super. 155, 183, 339 A.2d 764, 778-79 (1975).

${ }^{117}$ For example, in Sigel Estate, 169 Pa. Super. 25, 82 A.2d 309 (1951), aff'd, 381 
arise, a petitioner might nonetheless be tempted to allege all three grounds to triple his chances of success. If the statute were truly "protective" in nature that result would be desirable; but because, in fact, the statute presents a very serious threat to personal liberty, its scope should be narrowed, not widened, ${ }^{118}$ wherever the choice reasonably arises. ${ }^{119}$

\section{Extrastatutory Factors Influencing the Determination of Incompetency}

Several factors, for the most part not tied to any explicit statutory language, are often given as much weight by the courts as the express statutory standards. These factors should be analyzed to see if they are of positive value. Factors that are of value should be clearly articulated by the courts or included in the statute, so that they may be uniformly and predictably applied; those that are not of positive value should be disregarded by courts making incompetency decisions.

\section{Judicially Imposed Standards}

One of these factors is the question of consent by the subject of the incompetency declaration. Pennsylvania law apparently does not provide for the appointment of a guardian solely upon request that a guardian be appointed. At least one court, however, has considered the subject's consent a strong factor in the

Pa. 603, 114 A.2d 117 (1955), the only effect found was the likelihood that the subject would become the victim of designing persons. See text accompanying notes 66-68 supra.

${ }^{118}$ It is worthy of note that the origin of this statutory language in Pennsylvania was in an 1895 statute which provided that a guardian of the estate might be appointed whenever hereafter any person . . . shall become or be so weak in mind, that he or she is utterly unable to take care of his or her property and is therefore liable to dissipate or lose the same and to become the victim of designing persons ....

Act No. 220, § 1, [1895] Pa. Laws 300 (repealed 1907) (emphasis supplied). It thus appears that the legislature in 1895 did not intend the dissipation or victimization provisions to be separate grounds, but, rather, to be additional, necessary grounds for a finding of a need for guardianship. Some courts have followed the older formulation: Every day normal people are dissipating their property and every day normal people are the victims of designing persons but it is only in cases where persons are suffering from some mental disease or disorder and by reason of this infirmity are rendered incompetent to handle their property that the courts may step in and preserve their estates for their own good.

In re Aronson, 1 Pa. D. \& C.2d 638, 639 (Montgomery County C.P. 1954).

119 The statutory revision proposed by this Comment, set forth in note 151 infra, deletes likelihood of dissipation or victimization as "effects" permitting an adjudication of incompetency. 
decision to impose the guardianship. ${ }^{120}$ Consent would appear to be particularly relevant in some cases, for example when a person suffering from only a physical disability wants a guardian appointed. By taking into account the subject's consent, guardianship can be made more widely available to those who want it without making involuntary guardianship a threat to those for whom it is not absolutely necessary. ${ }^{121}$ The statutory standard of incompetence should be amended to provide that physically disabled persons may have guardians appointed if they consent. ${ }^{122}$

Another factor is the identity and interest of the petitioner for the declaration of incompetency. Petitions have too often been motivated by personal greed. ${ }^{123}$ In Mulholland's Estate ${ }^{124}$ the court noted that "the relationship of the petitioner not only to the accused but to the accused's property, with a view to the uncovering of any secret or selfish motive in the proceedings should always be made a specific point for the keenest and most searching judicial inquiry."125 Although the current statute does provide that " $[t]$ he court may dismiss a proceeding where it finds as a fact that the proceeding has not been instituted to aid or benefit the alleged incompetent," ${ }^{26}$ its language is not strong enough to respond adequately to the real danger of proceedings brought by interested petitioners. One solution would be to require an affirmative finding of fact that the proceeding was instituted for the good of the alleged incompetent. ${ }^{127}$ A finding of improper motivation should not, of itself, require that the petition be dismissed; but in such a case the petition should be

${ }^{120}$ See DuPuy Estate, 167 Pa. Super. 328, 74 A.2d 804 (1950).

${ }^{121}$ See text accompanying notes 39-43 supra.

${ }_{122}^{122}$ This suggested amendment is incorporated into the statutory revision set forth in note 151 infra.

${ }^{123}$ One court has noted "numerous instances where children have brought proceedings against an elderly surviving parent in order to compel distribution of the latter's property in accordance with the Intestate Laws rather than the desires of the parent." Axe Estate, 34 Pa. D. \& C.2d 625, 628 (Phila. County Orphans' Ct. 1964). For other examples of improperly motivated petitions, see Denner v. Beyer, $352 \mathrm{~Pa}$. 386, 388, 42 A.2d 747, 748 (1945); Mulholland's Estate, 217 Pa. 65, 68, 66 A. 150, 151 (1907); Bryden's Estate, 211 Pa. 633, 637, 61 A. 250, 251 (1905); Hudak Appeal, 170 Pa. Super. 74, 76, 84 A.2d 226, 227 (1951); Owens Appeal, 167 Pa. Super. 10, 12, 74 A.2d 705, 706 (1950); In re Brinton, 86 Pa. Super. 194, 198 (1925); Lancaster Estate, 13 Bucks County L. Rptr. 312, 321 (Orphans' Ct. 1963).

124217 Pa. 65, 66 A. 150 (1907).

${ }^{125} \mathrm{Id}$. at $68,66 \mathrm{~A}$. at 151 .

${ }^{126}$ Pa. Consol. STAT. ANN. tit. 20, § 5511 (a) (1975).

${ }^{127}$ For other solutions to this problem see Alexander, Surrogate Management of the Property of the Aged, 21 SyRACuse L. REv. 87, 167-68 (1969); Regan, supra note 5, at 616. 
granted only if it clearly appears that the guardianship will be in the best interest of the prospective ward. ${ }^{128}$

\section{Burden of Proof}

A third extrastatutory consideration is procedural due process, particularly burden of proof. The Pennsylvania courts have not moved very far in this direction, but the use of the word "accused" by the court in Mulholland's Estate ${ }^{129}$ may suggest that one court, at least, was aware of the analogy to criminal proceedings and of the need for strict protection of the procedural rights of the alleged incompetent.

This awareness has been more apparent in the related area of involuntary civil commitment of mentally disturbed persons. Two landmark cases of the 1970's, Lessard v. Schmidt ${ }^{130}$ and In re Ballay, ${ }^{131}$ have forcefully pointed out the need for strict standards of due process in such proceedings. A recent Pennsylvania decision, Commonwealth ex rel. Finken $v$. Roop, ${ }^{132}$ in which the court reversed a commitment order because of procedural deficiencies, addressed the analogy to criminal proceedings. The court's opinion noted that "involuntary commitment involves the same fundamental liberty that is at stake in criminal proceedings: the right of every individual to be unimpeded in the conduct of his affairs ..."133 Stating that the commitment statute operates "for the benefit of" the person committed "is actually only another formulation of the parens patriae argument" and does not lessen the requirements of due process, the court declared. "The serious deprivation of liberty and the unfortunate stigma which follow involuntary commitment render the distinction between 'criminal' and "civil' proceedings meaningless."134

Although civil commitment and involuntary guardianship proceedings cannot be equated for all purposes, they share the elements of stigma and significant restraint on the freedom to conduct one's affairs. Recognizing the force of this analogy could lead to a stricter burden of proof in guardianship proceedings.

In proceedings for adjudications of competency, the Penn-

${ }^{128}$ This suggestion is incorporated into the proposed statutory revision set forth in note 151 infra.

${ }^{129}$ Text accompanying note 125 supra.

130349 F. Supp. 1078 (E.D. Wis. 1972), vacated, 414 U.S. 473 (1974).

131482 F.2d 648 (D.C. Cir. 1973).

132234 Pa. Super. 155, 339 A.2d 764 (1975).

${ }^{133} \mathrm{Id}$. at $168-69,339 \mathrm{~A} .2 \mathrm{~d}$ at 771 (footnote omitted) (only three of seven judges joined in this part of the opinion).

${ }^{134}$ Id. at $171-72,339$ A.2d at $772-73$. 
sylvania courts generally require that "the burden of proof of establishing competency [be] by a fair preponderance of the evidence ...."135 Although the language of some opinions suggests that the burden in proceedings for declarations of incompetency is heavier, ${ }^{136}$ it is not clear that the courts have, in fact, demanded more than a preponderance. ${ }^{137}$ If the logic and language of Finken were followed, the courts would require petitioners in incompetency cases to meet at least the standard of "clear, unequivocal and convincing" proof. ${ }^{138}$ Such a burden of proof would help safeguard the alleged incompetent's rights and should deter the bringing of frivolous petitions. ${ }^{139}$

\section{Judicial Attitudes and Tendencies}

The Pennsylvania courts too often appear prone to "err on the safe side," and to let unwarranted guardianships stand. ${ }^{140}$ Implicit in this practice, of course, is the misconception that guardianship is "safe," a benevolent, protective institution that can do no harm. Although the statute permitting appointment of a guardian has often been called "preventative and protective in nature," ${ }^{41}$ some courts have apparently concluded that, in-

${ }^{135}$ See Nagle Estate, $418 \mathrm{~Pa} .170,172,210$ A.2d 262, 264 (1965).

${ }^{136}$ The supreme court observed in a footnote in In re Estate of Porter, 345 A.2d 171,174 (Pa. 1975) (quoting Myers Estate, $395 \mathrm{~Pa} .459,462-63,150$ A.2d 525, 527 (1959)), that the burden requires "evidence [that] is preponderating and points unerringly to mental incompetency." It should be noted that neither Myers nor Porter turned on the burden-of-proof issue.

${ }^{137}$ See generally Coulter Estate, 406 Pa. 402, 178 A.2d 742 (1962).

${ }^{138} 234 \mathrm{~Pa}$. Super. at $175,339 \mathrm{~A} .2 \mathrm{~d}$ at 774 (only three of seven judges joined in this part of the opinion).

The proposed statutory revision set forth in note 151 infra adopts this higher burden of proof standard.

${ }^{139}$ A comment on the Ballay standard noted that "[s]trict requirement of proof beyond a reasonable doubt may help to winnow the meaningless from the classifications and forge a new and more accurate statutory language." 42 U. CIN. L. REv. 751, 758 (1973).

${ }^{140}$ Justice Musmanno, dissenting from the Pennsylvania Supreme Court's refusal to reverse a trial court's denial of a petition for restoration to competency, noted:

One sure way not to make a mistake is not to do anything. Thus, the [trial court] ... handling the present case can remain safely within its ivory tower of non-criticism by refusing to touch the status quo .... The court below may have felt that if it was erring, it was doing so on the safe side ....

Pearlman Appeal, 400 Pa. 350, 352-53, 163 A.2d 530, 531 (1960) (Musmanno, J., dissenting). Justice Musmanno's criticism of the majority opinion seems to stem from the tendency of appellate courts in estate guardianship cases too readily to exercise their traditional deference to the factual determinations of trial courts. See, e.g., Coulter Estate, $406 \mathrm{~Pa} .402,413,178$ A.2d 742, 748 (1962). A stricter burden of proof would tend to counteract any such tendency to defer too willingly to trial court findings in this difficult and sensitive area.

${ }^{141}$ See note 9 supra. 
stead of serving as a warning not to declare a person incompetent unless he will really be protected, and some concrete harm prevented, the "preventative and protective" label is an indication that guardianship is always preventative and protective, and, therefore, less caution than normal is called for in applying the statute. ${ }^{142}$ For example, in Card Appeal, ${ }^{143}$ where the court dismissed on procedural grounds an appeal from a finding of incompetency, the court noted in passing that "[i]n the meantime, in view of the unfortunate contest between daughters for control of the estate of their aged and ailing mother, it is not amiss that the mother's assets are in the hands of a competent corporate fiduciary."144 Although the court may have been powerless to terminate the guardianship in this case, ${ }^{145}$ its language indicates a readiness to allow interference with the subject's freedom of choice in her property affairs. ${ }^{146}$ That it may not be "amiss"

${ }^{142}$ For a criticism of the tendency of the law to make mistaken predictions ("false positives") in situations where one is being "protected" (or society is being protected) against future deviant behavior, see von Hirsch, Prediction of Criminal Conduct and Preventive Confinement of Convicted Persons, 21 Buff. L. Rev. 717, 731 (1972): "In the context of . . preventive incarceration, we can afford little tolerance, indeed, of prediction methods that show a high yield of false positives. Here, mistakenly predicting nondangerous individuals to be dangerous is gravely damaging-for it can lead to their prolonged incarceration." This argument applies also to guardianship cases. See text accompanying notes $132-38$ supra.

${ }_{143} 177$ Pa. Super. 502, 110 A.2d 856 (1955).

$144 \mathrm{Id}$. at $506,110 \mathrm{~A} .2 \mathrm{~d}$ at 857.

145 The appeal was dismissed as not timely, $I d$. at $505,110 \mathrm{~A} .2 \mathrm{~d}$ at 857.

${ }^{146}$ Two recent decisions of the Pennsylvania Supreme Court, despite some expansive language, probably do not signify a departure from the approach to the statute typified by the cases discussed above.

In Urquhart Estate, 431 Pa. 134, 245 A.2d 141 (1968), the court reversed the orphans' court's order dismissing a petition for return to competency, noting that "no one should be deprived of dominion over his own property except for monumental reasons which include harm to the owner or to the property itself or to society in general." Id. at 135, 245 A.2d at 142. This statement will not solve many problems in this area of law, sweeping as it may seem at first glance. The court did not stop at "harm to the owner," as it should have, see text accompanying notes 106-12 supra, but went on to include harm to the property and to society in general. These latter two categories are broad enough to cover virtually any behavior that conflicts with a court's view of sound property management. Any large expenditure of principal could be said to "harm the property." "Society in general" could include prospective heirs, who are "harmed," arguably, if their inheritance is cut down. Furthermore, the court in Urquhart did not base its decision on the absence of "monumental reasons." It found "not the slightest evidence in all this litigation to suggest that Urquhart's property may be dissipated or that he may be the victim of designing persons." $431 \mathrm{~Pa}$. at 136, $245 \mathrm{~A} .2 \mathrm{~d}$ at 142 . The court properly concluded that the lower court's decision went against the weight of the evidence. The court did not, as its dictum may suggest, ground its decision on the lack of potential harm to petitioner or others.

More recently, in In re Estate of Porter, $345 \mathrm{~A} .2 \mathrm{~d} 171$ (Pa. 1975), the court reversed another denial of a petition for an adjudication of competency, emphasizing that "a guardianship may not be created, or continued, merely because the person lacks the 
that the assets are under a guardian's control is not the point; involuntary guardianship, no matter how desirable, is not justified unless strict standards of incompetency are met. ${ }^{147}$

Related to some courts' view of the statute as benign and harmless is their attitude toward the alleged incompetents. Often the courts seem quite paternalistic in their discussion of the foibles of eccentric individuals. ${ }^{148}$ Similarly, courts at times are given to substituting their own business judgment for that of the alleged incompetent. Their disapproval of his behavior may be a weighty factor in the adjudication of incompetence, even though the behavior may have been well within the proper statutory limits of competence. ${ }^{149}$ Aside from the impact of such intrusive attitudes or findings of incompetency, the danger that courts will seize upon unwise, unpleasant, or eccentric behavior as evidence of incompetence may cause some persons to shy away from behavior that does not clearly conform to societal norms. ${ }^{150}$

ability or experience needed to manage large sums of money." Id. at 173. The court noted that guardianship may be imposed only if the statutory standards are met. It also stated in a footnote that the burden for an initial adjudication of incompetency is heavier than that for an adjudication of competency, requiring proof that is "preponderating and points unerringly to mental incompetency." Id. at 174 n.6. But see note 136 supra \& accompanying text. That statement of the burden of proof may be an encouraging sign, but, because the court did not announce this formulation as increasing the burden which had been used in the past, the stricter language may represent a reaction to the circumstances of the case.

In general, it is doubtful that these decisions herald a new sensitivity to the rights of an alleged incompetent. The petitioner in Porter had been adjudged incompetent in 1926, forty-nine years before the decision, on the ground that he was an epileptic. At the 1974 hearing on his petition to terminate the incompetency, "three well-qualified experts testified that appellant is competent, and their testimony was uncontradicted." Id. at 174. These facts, like those of Urquhart, do not present the closer questions that sometimes cause courts to make questionable findings of incompetency. However, $U r$ quhart and Porter do suggest that the Pennsylvania Supreme Court now recognizes that inertia should not influence the decision with respect to a termination petition, and that the statutory standard of incompetency must be adhered to, at least in cases where it has clearly not been met.

${ }^{147}$ The need for courts to separate questions of justification and desirability is discussed in Comment, Adequacy of Mental Examination in Guardianship Proceedings, 25 OHIO ST. L.J. 307, 308-09 (1964). The author concludes that a trial court's discretion should extend only to the desirability of guardianship, and that a finding of incompetency according to the statutory definition should be a prerequisite to the exercise of that discretion.

${ }^{148}$ See, e.g., Nagle Estate, 418 Pa. 170, 172, 210 A.2d 262, 263-64 (1965); Shepherd Estate, 10 Pa. D. \& C.2d 712 (Delaware County C.P. 1956), aff'd per curiam, 391 Pa. 102, 137 A.2d 298 (1958); In re Guzzi's Estate, 50 Lackawanna Jur. 139, 140 (C.P. 1948).

${ }^{149}$ In Shepherd Estate, 10 Pa. D. \& C.2d 712 (Delaware County C.P. 1956), aff'd per curiam, $391 \mathrm{~Pa} .102$, $137 \mathrm{~A} .2 \mathrm{~d} 298$ (1955), the court noted that its decision to impose a guardianship was influenced by the alleged incompetent's having "entered into what in our judgment was an irresponsible and improvident agreement." Id. at 720.

${ }^{150}$ See note 14 supra. 


\section{Conclusion}

A declaration of civil incompetency resulting in a guardianship of the estate is a very serious matter, having drastic legal, social, and psychological effects for a person declared incompetent. Accordingly, such a declaration should be granted only as a last resort, when no other remedy is available. When an adjudication of incompetency is sought, the courts should abandon the myth that such proceedings are "preventative and protective," and should grant the petition only when strict justification is shown, in the absence of consent by the alleged incompetent.

The current Pennsylvania incompetency statute is designed to include within its reach as many persons who might benefit from guardianship as possible. That broad reach should be preserved for persons who desire, and will consent to, the. appointment of a guardian. For unconsented guardianships, however, the statute should require a sufficient finding of mental disturbance to justify state interference with personal freedom; it should require that there be no effective alternative to guardianship; and it should require a finding of actual hardship resulting from inability to manage property, rather than a mere likelihood of dissipation of the estate or victimization by designing persons. The statute should also impose a stricter burden of proof on the petitioner for an unconsented declaration of incompetency, and a lighter burden on the petitioner for termination of incompetency. ${ }^{151}$

${ }^{151}$ The following proposed revision of sections 5501 and 5511 of the Decedents, Estates and Fiduciaries Code, PA. Consol. STAT. ANN. tit. 20, $\S 5501,5511$ (1975), incorporates the changes recommended in this Comment.

$\S 5501$. Meaning of Disabled Person

"Disabled person" means a person who, because of mental or physical in-

firmities, mental illness, or mental deficiency:

(1) is unable to manage his property; or

(2) lacks sufficient capacity to make or communicate responsible decisions concerning his person.

$\S 5511$. Petition and hearing; examination by court-appointed physician

(a) Resident.-

(1) The court, upon petition and a hearing may, upon clear, unequivocal, and convincing proof, find a person domiciled in the Commonwealth to be disabled and appoint a guardian or guardians of his person or estate: Provided that no person's estate shall be placed under guardianship without his consent unless at the time of the hearing as a result of mental infirmities, mental illness, or mental deficiency he lacks substantial capacity either to appreciate the harmful character of his conduct or to conform his conduct to the requirements of his own well-being; And provided further that no person's estate shall be placed under guardianship without his consent unless his inability to manage his property is of such a nature and degree that 
The attitude of the Pennsylvania courts has tended to favor paternalistic interference with alleged incompetents' management of their own property. It would be a far better approach for the lawmakers and judges to leave individuals free to make their own mistakes, absent an overriding need for state intervention to prevent a personal catastrophe.

substantial harm will befall him as a direct result of such inability and unless no other suitable property management arrangement to which he will consent is available.

(2) The petitioner may be any person interested in the alleged disabled person's welfare. The court shall dismiss a proceeding unless it finds that the proceeding was instituted to aid or benefit the alleged incompetent or that, despite the proceeding not having been instituted to aid or benefit the alleged disabled person, it clearly appears that the guardianship will be in the best interest of the prospective ward. Notice of the petition and hearing shall be given in such manner as the court shall direct to the alleged disabled person, to all persons residing within the Commonwealth who are sui juris and would be entitled to share in the estate of the alleged disabled person if he died intestate at that time, and to such other parties as the court may direct. The hearing may be closed to the public and without a jury unless the alleged disabled person or his counsel objects. The hearing shall be closed and with or without a jury if the person alleged to be disabled or his counsel so requests. The alleged disabled person shall be present at the hearing unless:

(a) the court is satisfied, upon the presentation of positive testimony, that because of his physical or mental condition his welfare would not be promoted by his presence; or

(b) it is impossible for him to be present because of his absence from the Commonwealth. It shall not be necessary for the alleged disabled person to be represented by a guardian ad litem in the proceeding.

(b) Nonresident.-The court may find a person not domiciled in the Commonwealth, having property in the Commonwealth, to be disabled and may appoint a guardian of his estate. The appointment may be in the manner provided in subsection (a) of this section, or upon the submission of an exemplified copy of a decree establishing his incompetency in another jurisdiction. The court shall give preference in its appointment to the foreign guardian of the nonresident disabled person, unless it finds that such appointment will not be for the best interests of the disabled person.

(c) Court-appointed physician.-Upon the filing of a petition the alleged disabled person may be examined by a physician appointed by the court who shall submit his report in writing to the court and to the parties before the hearing.

Substitution of "disabled person" for "incompetent" in the present statute would also, of course, require technical conforming amendments throughout chapter 55 of the Code. 